\title{
Enzyme Multiplied Immunoassay Technique
}

National Cancer Institute

\section{Source}

National Cancer Institute. Enzyme Multiplied Immunoassay Technique. NCI Thesaurus.

Code C111196.

A type of homogenous immunoassay in which sample is applied to a reagent mixture of enzyme-labeled lig and, antibody, and substrate. Substrate binding to enzyme leads to inactivation and unlabeled-lig and in the sample can be quantified by colorimetric analysis. 